\title{
Mediating factors influencing the capacities of enterprise network performance
}

\author{
Zhou Lu Lin, James Onuche Ayegba
}

\begin{tabular}{|c|c|}
\hline \multicolumn{2}{|r|}{ A B STRACT } \\
\hline \multicolumn{2}{|c|}{$\begin{array}{l}\text { Objective: The study examined the mediating factors influencing the capacities and } \\
\text { performance of enterprise network using some food and beverages enterprises in } \\
\text { Lagos, Nigeria. }\end{array}$} \\
\hline \multicolumn{2}{|c|}{$\begin{array}{l}\text { Research Design \& Methods: Primary source of data was employed in the study. The } \\
\text { data collected from five hundred and thirty nine (539) respondents was analysed with } \\
\text { the use of factor analysis which brings out the beauty and reality of the study. Six hun- } \\
\text { dred and fifty seven (657) middle and top level management staff of six food enter- } \\
\text { prises and beverage enterprises particularly the manufacturing ones through a purpos- } \\
\text { ive sampling technique. }\end{array}$} \\
\hline \multicolumn{2}{|c|}{$\begin{array}{l}\text { Findings: When the original ten variables were analyzed, four variables were extracted } \\
\text { from the analysis with eigenvalues greater or equal to 1, which explained } 36.414 \text { per- } \\
\text { cent of the entire variance. Hence, the mediating factor influencing the capacities of } \\
\text { enterprise network performance is Strategic Decision-Making Capacity (SDMC), Tech- } \\
\text { nological Capacity (TC), Efficiency Enterprise Capacity (EEC), and Complexity in Technol- } \\
\text { ogy or Technological Turbulence (TT). }\end{array}$} \\
\hline \multicolumn{2}{|c|}{$\begin{array}{l}\text { Contribution \& Value Added: Finally, factors influencing the capacities of network per- } \\
\text { formance are Strategic Decision Making Capacity (SDMC), Technological Capacity (TC), } \\
\text { Efficiency Enterprise Capacity (EEC), and Complexity in Technology or Technological } \\
\text { Turbulence (TT). The result of the study is essential because of its significant contribu- } \\
\text { tion to the body of knowledge and literature regarding strategic management. }\end{array}$} \\
\hline Article type: & \\
\hline Keywords: & \\
\hline & $P \angle 4, P 44, D \angle 2, D \angle 3, D \angle$ \\
\hline \multicolumn{2}{|r|}{ Article accepted: 15 September 2020} \\
\hline
\end{tabular}

\section{Suggested citation:}

Lin, Z.L., \& Ayegba, J.O. (2020). Mediating factors influencing the capacities of enterprise network performance. International Entrepreneurship Review (previously published as International Entrepreneurship / Przedsiębiorczość Międzynarodowa), 6(3), 7-19. https://doi.org/10.15678/IER.2020.0603.01 


\section{INTRODUCTION}

The situation of business enterprises in the past years has been exceptional, transformative, highly competitive, and in a highly technological environment which is tumultuous. These changes spring up because of technology dynamics, market dynamics, management dynamic, business operational dynamics (demand and supply ends), and others which have direct and indirect connotation on the performance of enterprises. Ahmad et al. (2014) noted that enterprises are facing these and more challenges because of the term "dynamics" which affects the overall business performance.

Food enterprises and beverage enterprises are not exempted from the sweeping transformation as they have experienced increasing levels of competition during the last one decade, which create significant issues to maintaining economic balance. It was revealed in the study that there are more challenges posed which seems to be higher than enterprise survival. This challenge is experienced with the tendency at which enterprises thrive during the situation of increased competition. In fact, in the high level of competition that is predominant among all enterprises and challenging situation of the Nigerian economy are crucial factors that rooted enterprise networks to be of essence in realizing enterprise revitalization (Zahra et al., 2006).

Ahmad and Pirzada (2014) also discovered that enterprise networks have significant roles in bringing a level of buoyancy to a nation's economic situations, which is laudable in fulfilling economic development. Because of this importance, there is a need for enterprises to form a formidable network (Hashim et al., 2018), which will fortify them to stand against all economic odds (Zhu et al., 2013). The study was purposed to examine the mediating factors influencing the capacities of enterprise network performance in some selected food and beverages industry in Lagos, Nigeria using factor analysis.

\section{LITERATURE REVIEW}

The position of enterprises in the world development cannot be far-fetched from or beyond the major purpose of realizing economic development. Realizing the performance of enterprises, there is need for the enterprise owners themselves to form a formidable network. Obasi (2013) noted that enterprise networks are essential to achieve development and industrialization. For an enterprise to be transformed and rooted into the unforeseeable future, its capability to expand and broaden horizons for significant outputs must be on the key objectives if not as the organization aim.

FMCGs and CMGs are sectors in Nigeria that have experienced and still experiencing various issues, such as reduced quality of products, less customer satisfaction on products, and many more which are caused as a result of economic imbalances, increasing competition, importation of similar products, increasing petroleum prices, naira devaluation (Industrial Report, 2016). This has created a form of tumultuous environment for most enterprises. Significant numbers of value creation and dynamic capabilities have be identified in strategic management, among are strategic decision-making, product and knowledge creation, technological capability, product innovation capability, top managers alliance, and strategic flexibility (Ibidunni et al., 2014; Oghojafor et al., 2014; Zhang, 2007; Ibidunni \& Inelo, 2004). 
The enterprise networks must continuously develop dynamics to new resources that will enhance their sustenance in the unendingly environment (Eisenhardt \& Martins, 2000; Oladele et al., 2010; Rindova \& Kotha, 2001; Teece et al., 1997). The creation of value and competitive advantage becomes realistic when enterprises are able to form networks for making best use of resources, opportunities, and capabilities (Teece, 2009). This will enhance highly competitive advantage among the group of enterprises that are able to team up for network. This is highly needed in the modern era (Chirico \&Salvato, 2008).

In the views of Rehman and Saeed (2015) and (Wong, 2013), dynamic capability is a form of facility for any organization to flourish in the present dynamic environment. Competitive advantages are secured when intensifying business sustainable options (Seung, 2014), and creating value (Hedvall et al., 2019; Hashim et al., 2018; Guo et al., 2018; Rodrigo-Alarcón et al., 2018; Oghojafor et al., 2014; Sherazi et al., 2013; Machirori \& Fatoki, 2013)

Ibidunni and Inelo (2004) noted that sooner, the managers and owners of enterprises will engage in strategic and innovative thinking to sustain the increasing business dynamics and to enhance success of enterprise networks. In the perspective of Eisenhardt et al. (2010), for enterprise to sustain in the ferocious competitive environment, there is a need to develop strategies that will enhance more customer demand, changing the legal frameworks and implementing more technology solutions (Shimizu \& Hitt 2004). Studies of Stock \& Wennberg (2009); Oluwale et al. (2013) have shown that product innovation is a valueaddition activity for enterprises, and Kemper et al. (2013) noted that it has been an approach for realizing competitive advantage.

Though some in some studies, it was theoretically revealed that product innovation is a factor that determines enterprise survival (Damanpour \& Wischnevsky, 2006; Daniel \& Wilson, 2003; Damanpour \& Gopalakrishnan, 1999; Stock\& Wennberg, 2009). Rosenbuschet al. (2011) noted that empirical results of many studies are contradictory, especially those that treated small and medium-sized enterprises (SMEs). Some empirical researches reveal a positive and significant nexus between product innovation and enterprise survival (Alegre \&Chiva, 2013, while other researches reveals negative nexus (Grewal $\&$ Tansuhaj (2001). From the result obtained in various studies, there were suggestions that other factors may be affecting the dynamic relationship that existed between innovation on products and the survival of enterprises. In view of this, there is thus a need to embark on the study based on selected foods and beverages enterprises. Based on this background, the study is set to examine the factors mediating between the influencing the capacities of enterprise network performance employing some selected foods and beverages enterprises in Lagos, Nigeria.

The research covers 6 foods and beverage enterprises that are quoted in the Nigeria Stock Exchange (NSE) of the manufacturing sector. This study was carried out because of the alarming report of the Manufacturing Association of Nigeria (MAN) that about 60 percent of the manufacturing company in Nigeria is not functioning well, while 30 percent have gone on comatose, and only 10 percent are operating at a sustainable level (Olamade et al., 2013). Food and beverage sector was among the large-scale quoted food and beverages enterprises, from which this study select six (Honeywell Flour Mills Nigeria, 7-Up Bottling Company, Nestle Nigeria, Flour Mills Nigeria, Dangote Flour Mill Nigeria, and Unilever Nigeria) in Lagos State, Nigeria. All are listed in the Nigeria Stock Exchange (NSE). The study will cover Lagos state because the state is currently the industrial, commercial and financial hub of Nigeria. 


\section{MATERIAL AND METHODS}

This section critically elucidates the approaches that were adopted in realizing the aim of this research. This study will employ quantitative approach that entails a form of survey research as research design for the purpose of exploring the observable fact, and presents a well robust explanation to the identified problems that the study seeks to address.

\section{Research Design}

This study adopts a survey research design which will assist in pointing out challenges and managerial dynamics and issues relating to operations in Food and Beverages sector particularly in Nigerian in addition to considering the dimensions of enterprise networks in the form of enterprise supplier interactions, enterprise customer connections and enterprise competitors' interactions, and to moderate the consequence of environmental dynamics in the connection between Dynamic Capacities and Enterprise Networks on Company's Performance.

\section{Sampling}

The sample for this study was achieved based on the 14 companies that were listed in the Nigerian Stock Exchange (NSE) bulletin of 2014 as indigenous and multinational enterprises. Among the 14 companies, 6 companies were tagged as foods and beverages enterprises, but 6 enterprises will be selected for this study because of the ease of getting information as earlier explained by (Udemba, 2015; Akpan et al., 2016).

According to Zikmund (2003), the various error allowances was determined and the suitable one was chosen based on the discretion of the researcher. The chosen error allowance of 0.04 was employed to establish the sample size as shown in the equation: $\mathrm{n}=\mathrm{Z}^{2} / 4 \mathrm{E}^{2} ; \mathrm{n}$ is denoted as the Sample size; $\mathrm{Z}$ is denoted as the $\mathrm{Z}$ score (confidence interval which is 2.05; $E$ is denoted as the Error allowance which is 0.04 .

Based on the sample size formula, the number of sample size was 656.6406 , which is approximately 657 . On this note, 657 questionnaires will be distributed to respondents whom are middle and top managers in the listed foods and beverage companies.

Regarding the recommendations of the sample size for factor analysis, the recommendations are more often than not stated with respect to either the least sample size $(N)$ or the least ratio of $\mathrm{N}$ to the number of variables, i.e., the number of survey items that is being subjected to factor analysis (Adeniran, Stephens \& Akinsehinwa, 2020). Gorsuch (1983) recommended a minimum of 100 sample size for factor analysis, Guilford (1954) argued that sample size should be at least 200, while Cattell et al. (1970) made recommendation with a minimum of 250 number of sample size. Also, the following guidance was provided with respect to the determination of sample size adequacy Comrey and Lee (1992), such that the sample size of hundred is poor; sample size of two hundred is fair; sample size of three hundred is good; sample size of five hundred is very good; and sample size of one thousand or more is excellent. In this study, the sample size of six hundred and fifty seven (657) is adequate for factor analysis and reporting as rooted in earlier studies. 
Primary data was extracted through a structured questionnaire that was distributed to top and middle management officers responsible for the strategic decision and direction of the companies. This study employed close-ended questions of Likert type five points scale which was modified

\section{Model Specification for Factor Analysis}

Adeniran et al. (2020) posits that in the situation where by the observed variables are $X_{1}$, $X_{2} \ldots . X_{n}$, the dominant factors are $F_{1}, F_{2} \ldots F_{m}$ and the exclusive factors are $U_{1}, U_{2} \ldots U_{n}$, the variables may be expressed as linear functions of the factors:

$$
\begin{aligned}
& X_{1}=a_{11} F_{1}+a_{12} F_{2}+a_{13} F_{3}+\ldots+a_{1 m} F_{m}+a_{1} U_{1} \\
& X_{2}=a_{21} F_{1}+a_{22} F_{2}+a_{23} F_{3}+\ldots+a_{2 m} F_{m}+a_{2} U_{2} \\
& \ldots \\
& X_{n}=a_{n 1} F_{1}+a_{n 2} F_{2}+a_{n 3} F_{3}+\ldots+a_{n m} F_{m}+a_{n} U_{n}
\end{aligned}
$$

Every equation that is represented is known to be a regression equation; the coefficients $a_{11}, a_{12} \ldots a_{n m}$ were identified with factor analysis which suitably replicated the observed variables from the factors.

\section{RESULTS}

The targeted participants in the investigation were approved to voluntarily take part in the exercise. In furtherance to that, the aim of the study was made comprehensible to them. Intensive and joint effort was ensured to realize confidentiality, secrecy and anonymity of information given by the respondents; also, they were assured that all information elicited from them was used solely for the rationale of this work. Research assistants were educated regarding the etiquettes in research for the purpose of ensuring absolute compliance to research ethics during the process of conducting the study.

The following were limitations encountered by the researcher on the acceptance of the methodology: difficulty in data gathering from some of the enterprises however, it was achievable with the help of some staff; generally, the core assumptions of multiple regressions are quite limited because of the presence of normality in the stochastic disturbance terms (error terms), the presence of multicollinearity and homoscedasticity between any pair of independent variables and the error terms could result to unauthentic result which is the reason for making provision for stochastic disturbance term or error term or residual in the model; and hierarchical regression analysis is employed to determine the effect of enterprise networks on the performance of the company through a reconciling task of dynamic capacities, which is made doable because of the inadequate quantification of variables; it may not be apposite if the study seeks to examine more complex relationship.

From the sample size calculated to about six hundred and fifty-seven (657) which equals to the total copies of questionnaires administered by the researcher targeted at the middle managerial staff and the top managerial staff of particular beverages and food enterprises in Lagos State, five hundred and thirty-nine (539) which is about 82 percent copies of questionnaire were valid and returned for data analysis and reporting. The remaining (118) copies of questionnaire were not used in the data analysis because of different invalidity issues. Hence, all the valid questionnaires returned were processed for data analysis, and the response was revealed in Table 1. 
Table 1. Response rate of respondents

\begin{tabular}{|c|c|c|}
\hline Questionnaire & Frequency & Percentage \\
\hline Administered & 657 & \\
\hline Returned & 539 & 82 \\
\hline Not Returned & 118 & 18 \\
\hline
\end{tabular}

Source: Field Survey (2020).

Fadare and Adeniran (2018) posit that a response rate of fifty percent and above regarding the copies of questionnaire returned is appropriate for data analysis. Hence, the response rate of eighty-two (82) percent copies of questionnaire returned for this study is appropriate for establishing data analysis.

Factor analysis was adopted to achieve this aim. Several variables have been employed to explicate the complex interconnections and interrelationships of variables. In this regard, the few fundamental variables that are germane to this study remained to be determined. The systematic relationships among these established variables are presented on rank order scales data (Nimalathasan, 2009).

Factor analysis is a technique adopted in achieving statistical analysis. It belongs to the family of General Linear Model (GLM) procedures. It is designed to inform the essential structure for understanding a phenomenon (Spearman, 1904). Factor analysis entails the following such as correlation matrix, communality, eigenvalues, factor rotation, factor loadings, entire variance explained and others.

Table 2 below shows the correlation matrix to identify the direction, and degree of relationships between the variables on five point Likert scales. Correlation matrix in Table 2 revealed the interconnection between the ten (10) variables: Innovation Product Capacity (IPC), Sales Growth Capacity (SGC), Strategic Decision Making Capacity (SDMC), Enterprise Survival Capacity (ESC), Efficiency Enterprise Capacity (EEC), Technological Capacity (TC), Strategic Flexibility Capacity (SFC), Competitive Advantage (CA), Competitive Intensity (Cl), and Complexity in Technology or Technological Turbulence (TT). The interconnection between SGC and IPC is very strong and positive at 0.840 . The interconnection between ESC and SDMC is very strong and positive at 0.803 . The interconnection between TC and EEC is weak and positive at 0.288 . The interconnection between CA and SFC is very strong and positive at 0.866 . The interconnection between $\mathrm{Cl}$ and SDMC, $\mathrm{Cl}$ and ESC are very strong and positive at 0.769 and 0.953 respectively. The interconnection between $T T$ and SDMC, $T$ T and ESC, $\mathrm{T}$ and $\mathrm{Cl}$ are very strong and positive at $0.791,0.927$, and 0.886 respectively.

It is pertinent to note that there are suspects of multicolinearity (high correlations) between the following interconnected variables: $\mathrm{Cl}$ and ESC, TT and ESC which correlation values are more than 0.85. Table 3 depicts the Kaiser Meyer Olkin (KMO) test. According to Adeniran \& Olorunfemi (2019), Kaiser Meyer Olkin (KMO) is used to determine the level of numerical adequacy of factor analysis that is supposed to be carried out. The determination of KMO that is between 0.9 and 0.8 is excellent, $\mathrm{KMO}$ that is between 0.7 and 0.6 is very good, KMO that is between 0.6 and 0.5 is good, From Table 3, the KMO result of 0.685 is very good and acceptable for performing factor analysis, and it is significant at 0.000 which implies that the data do not generate an identity matrix, the data is normal, suitable and acceptable multivariate for factor analysis. 
Table 2. Correlation Matrix

\begin{tabular}{|c|c|c|c|c|c|c|c|c|c|c|c|}
\hline \multicolumn{12}{|c|}{ Correlation Matrix ${ }^{a}$} \\
\hline & & IPC & SGC & SDMC & ESC & EEC & TC & SFC & CA & $\mathrm{Cl}$ & TT \\
\hline \multirow{10}{*}{ 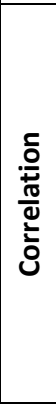 } & IPC & 1.000 & 0.840 & -0.023 & 0.016 & 0.018 & -0.095 & 0.031 & -0.002 & 0.038 & -0.025 \\
\hline & SGC & & 1.000 & -0.051 & -0.069 & 0.072 & -0.044 & -0.008 & -0.005 & -0.056 & -0.105 \\
\hline & SDMC & & & 1.000 & 0.803 & 0.183 & 0.052 & -0.012 & -0.027 & 0.769 & 0.791 \\
\hline & ESC & & & & 1.000 & 0.193 & 0.071 & 0.032 & 0.005 & 0.953 & 0.927 \\
\hline & EEC & & & & & 1.000 & 0.288 & 0.182 & 0.085 & 0.199 & 0.164 \\
\hline & TC & & & & & & 1.000 & 0.145 & 0.102 & 0.066 & 0.090 \\
\hline & SFC & & & & & & & 1.000 & 0.866 & 0.007 & -0.007 \\
\hline & CA & & & & & & & & 1.000 & 0.001 & -0.019 \\
\hline & $\mathbf{C l}$ & & & & & & & & & 1.000 & 0.886 \\
\hline & TT & & & & & & & & & & 1.000 \\
\hline
\end{tabular}

Source: SPSS Version 20 (2020).

Table 3. KMO and Bartlett's Test

\begin{tabular}{|c|c|c|}
\hline \multicolumn{2}{|c|}{ Kaiser-Meyer-Olkin Measure of Sampling Adequacy. } & $\mathbf{0 . 6 8 5}$ \\
\hline \multirow{3}{*}{ Bartlett's Test of Sphericity } & Approx. Chi-Square & 4486.783 \\
\cline { 2 - 3 } & Df & 45 \\
\cline { 2 - 3 } & Sig. & 0.000 \\
\hline
\end{tabular}

Source: SPSS Version 20 (2020).

Table 4 depict communality through Principal Component Analysis (PCA). Communality is the percentage measure of a variable's variation that is being explained by the factors. It is the portion of variance that an initial variable shared with the other variables that is entailed in the analysis. From Table 4, four factors that were identified are SDMC (1), TC (2), EEC (3), and TT (4). The Technological Turbulence (TT) however shows a sign of multicolinearity. Table 5 revealed that the four variables account for 36.414 percent variance explained.

Table 4. Communalities

\begin{tabular}{|l|c|c|c|}
\hline \multicolumn{1}{|c|}{ Variables } & Initial & Extraction & Hierarchy \\
\hline IPC & 1.000 & 0.920 & \\
\hline SGC & 1.000 & 0.920 & 1 \\
\hline SDMC & 1.000 & 0.785 & 3 \\
\hline ESC & 1.000 & 0.954 & 2 \\
\hline EEC & 1.000 & 0.637 & \\
\hline TC & 1.000 & 0.683 & \\
\hline SFC & 1.000 & 0.935 & 4 \\
\hline CA & 1.000 & 0.935 & \\
\hline CI & 1.000 & 0.918 & \\
\hline TT & 1.000 & 0.912 & \\
\hline
\end{tabular}

Note: Extraction Method: Principal Component Analysis.

Source: SPSS Version 20 (2020) 
Table 5. Entire variance Explained

\begin{tabular}{|c|c|c|c|c|c|c|c|c|c|}
\hline \multirow[b]{2}{*}{ 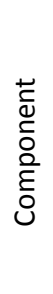 } & \multicolumn{3}{|c|}{ Initial Eigenvalues } & \multicolumn{3}{|c|}{$\begin{array}{l}\text { Extraction Sums } \\
\text { of Squared Loadings }\end{array}$} & \multicolumn{3}{|c|}{$\begin{array}{l}\text { Rotation Sums } \\
\text { of Squared Loadings }\end{array}$} \\
\hline & 焉 & 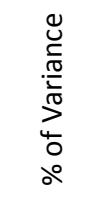 & 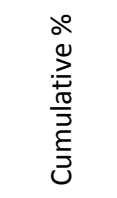 & $\begin{array}{l}\bar{\pi} \\
\stackrel{0}{\circ} \\
1\end{array}$ & 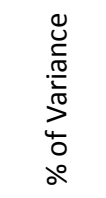 & 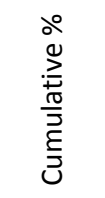 & 焉 & 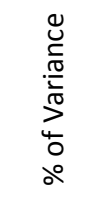 & 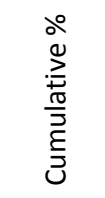 \\
\hline 1 & 3.641 & 36.414 & 36.414 & 3.641 & 36.414 & 36.414 & 3.579 & 35.788 & 35.788 \\
\hline 2 & 1.957 & 19.570 & 55.984 & 1.957 & 19.570 & 55.984 & 1.865 & 18.650 & 54.438 \\
\hline 3 & 1.850 & 18.495 & 74.479 & 1.850 & 18.495 & 74.479 & 1.854 & 18.538 & 72.976 \\
\hline 4 & 1.152 & 11.522 & 86.001 & 1.152 & 11.522 & 86.001 & 1.303 & 13.025 & 86.001 \\
\hline 5 & 0.693 & 6.928 & 92.929 & & & & & & \\
\hline 6 & 0.284 & 2.842 & 95.771 & & & & & & \\
\hline 7 & 0.160 & 1.595 & 97.366 & & & & & & \\
\hline 8 & 0.118 & 1.176 & 98.542 & & & & & & \\
\hline 9 & 0.109 & 1.093 & 99.635 & & & & & & \\
\hline 10 & 0.037 & 0.365 & 100.000 & & & & & & \\
\hline
\end{tabular}

Note: Extraction Method: Principal Component Analysis.

Source: SPSS Version 20 (2020)

When the original ten variables were analysed, four variables were extracted from the analysis with eigenvalues greater or equal to 1, which accounted for 36.414 percent of the entire variance. Hence, the mediating factor influencing the capacities of enterprise network performance are Strategic Decision Making Capacity (SDMC), Technological Capacity (TC), Efficiency Enterprise Capacity (EEC), and Complexity in Technology or Technological Turbulence (TT).

This study is corroborates the findings of Ibidunni et al. (2014); Jegede et al. (2012); Mohd et al. (2013); Olamade et al. (2013); Obembe et al. (2014) which discover one or more variables as mediating factor influencing the capacities of enterprise network performance. Also, it is also in connection with other studies that were earlier carried out in Europe, Asia, and America. For example, Strategic Decision Making Capacity (SDMC), Technological Capacity (TC), Efficiency Enterprise Capacity (EEC), and Complexity in Technology or Technological Turbulence (TT) in Malaysia can be properly traced out in the effect of government policy framework for improving business as it is circumspectly considered for enterprises (Rasiah, 2002). There seems to be focus on innovation policy in the studies conducted in the U.K. (Foreman-Peck, 2013). This is the same with the studies in Brazil on the impact of development policy on enterprises' performance (Garoneet al., 2015).

\section{CONCLUSIONS}

The study examined the mediating factors influencing the capacities of enterprise net-work performance of food and beverages enterprises in Lagos, Nigeria. Six hundred and fifty seven (657) middle and top level management staff of six food enterprises and beverage enterprises particularly the manufacturing ones through a purposive sampling technique. The study made 
use of primary source of data. The data collected from five hundred and thirty nine (539) respondents was analysed with the use of factor analysis which brings out the beauty and reality of the study. From the study, Statistical Package for Social Sciences (SPSS) version 23 was used alongside Excel (Window 10) to code, compute, and process the data.

When the original ten variables were analysed, four variables were extracted from the analysis with eigenvalues greater or equal to 1 , which accounted for 36.414 percent of the entire variance. Hence, the mediating factor influencing the capacities of enterprise network performance are Strategic Decision Making Capacity (SDMC), Technological Capacity (TC), Efficiency Enterprise Capacity (EEC), and Complexity in Technology or Technological Turbulence (TT). Finally, factor analysis revealed that the mediating factor influencing the capacities of enterprise network performance are Strategic Decision Making Capacity (SDMC), Technological Capacity (TC), Efficiency Enterprise Capacity (EEC), and Complexity in Technology or Technological Turbulence (TT).

Policy Implications: The result that stemmed out of the study is essential because of its significant contribution to the body of knowledge and literature regarding strategic management. Finally, From the findings, recommendations were suggested that among the mediating factors examined on enterprise network capacities, factor analysis revealed that the mediating factor influencing the capacities of enterprise network performance are Strategic Decision Making Capacity (SDMC), Technological Capacity (TC), Efficiency Enterprise Capacity (EEC), and Complexity in Technology or Technological Turbulence (TT). It is therefore essential for the management of enterprises to prioritize those indicators for realizing better performance.

Suggestions for Further Research: Since this study is limited to ten variables, and six food and beverage enterprises across Lagos, Nigeria, future studies may consider more variables that will be more robust for factor analysis. Also, samples may be drawn from enter-prises across south-western states. Comparative analysis with other countries may be conducted by the researcher in future studies. It may also be conducted by researchers that want to imitate the study.

Research Limitations: Since this study is limited to ten variables, and six food and beverage enterprises in Lagos. These enterprises were among the large-scale quoted food and beverages enterprises (Honeywell Flour Mills Nigeria, 7-Up Bottling Company, Nestle Nigeria, Flour Mills Nigeria., Dangote Flour Mill Nigeria, and Unilever Nigeria) in Lagos State, Nigeria. Finally, factor analysis was adopted for data analysis

\section{REFERENCES}

Adeniran, A.O., Stephens, M.S., \&Akinsehinwa, F.O. (2020). Factor Analysis of Passengers' Satisfaction at Murtala Muhammed Airport (MMA2). Aeronautics \& Aerospace Open Access Journal,4(1), 13-24. DOI: 10.15406/aaoaj.2020.04.00101

Adeniran, A.O., \&Olorunfemi, S.O. (2019). Important Service Indicators of Public Transport System inAkure-Owo, Nigeria. Scientific Research Impact, 5(6), 285-301

Ahmad, N., Othman, S.N., \&Lazim, H.M. (2014). A review of technological capability and performance relationship in manufacturing companies. 2014 International Symposium on Technology Management and emerging technologies (ISTMET 2014). 
Ahmad, Y., \& Pirzada, D.S. (2014). Using analytic hierarchy process for exploring prioritization of functional strategies in auto parts manufacturing SMEs of Pakistan. Center for Advanced Studies in Engineering (CASE), 4(4), 15-31. doi:10.1177/2158244014553560

Akpan, P.L., Ikon, C., \& Momoh, N. (2016). Economic environment and performance of food and beverages sub-sector of a developing economy: Nigeria. International Journal of Recent Research in Commerce Economics \&Management, 3 (3), 85-90.

Alegre, J., \&Chiva, R. (2013). Linking entrepreneurial orientation and firm performance: The role of organizational learning capability and innovation performance. Journal of Small Business Management, 51(4), 491-507. doi:10.1111/jsbm.12005

Catell, R.B., Eber, H.W., \&Tatsuoka, M.M. (1970). The H\&book for the Sixteen Personality Factor Questionnaire. Champaign, IL: Institute for Personality and Ability Testing.

Chirico, F., \& Salvato, C. (2008). Knowledge integration and dynamic organizational adaptation in family enterprises. Family Business Review. 21 (2), 169-181.

Comrey, L.A., \& Lee, H.B. (1992). A First Course in Factor Analysis (2nd ed.). Lawrence Erlbaum Associates.

Damanpour, F., \& Gopalakrishnan, S. (1999). Organizational adaptation and innovation: The dynamics of adopting innovation types. In K. Brockoff, A. Chakrabarti, and J. Hauschildt (Eds.), The dynamics of innovation: Strategic and managerial implications (pp. 57-80). Berlin, Germany: Springer-Verlag.

Damanpour, F., \&Wischnevsky, D.J. (2006). Research on innovation in organizations: Distinguishing innovation-generating from innovation-adopting organizations. Journal of Engineering and Technology Management, 23(4), 269-291. doi:10.1016/j. jengtecman.2006.08.

Daniel, E., \& Wilson, H.N. (2003). The role of dynamic capabilities in business transformation. European Journal of Information Systems, 12(4), 282-96.

Eisenhardt, K.M., \& Martins, J.A. (2000). Dynamic capabilities: What are they? StrategicManagement Journal, 21, 1105-1121.

Fadare, S.O. \& Adeniran, A.O. (2018) Comparative analysis of public operated airport terminal and concessioned airport terminal in Lagos, Nigeria. Discovery, 54(272): 304-318.

Foreman-Peck, J. (2013). Effectiveness and efficiency of SME innovation policy. Small Business Economics, 41(1), 55-70. doi:10.1007/s11187-012-9426-z

Garone, L.F, Maffioli, A., de Negri, J.A., Rodriguez, C.M., \& Vazquez-Bare, G. (2015). Cluster development policy, SME's performance, and spillovers: Evidence from Brazil. Small Business Economics, 44(4), 925-948. doi:10.1007/s11187-014-9620-2

Gorsuch, R.L. (1983). Factor Analysis (2nd ed.). Erlbaum.

Grewal, R., \&Tansuhaj, P. (2001). Building organizational capabilities for managing economic crisis: The role of market orientation and strategic flexibility. Journal of Marketing, 65(2), 67-80.

Guilford, J.P. (1954). Psychometric methods (2nd ed.). McGraw Hill.

Guilford, J.P. (1967). The Nature of Human Intelligence. NY: McGraw-Hill.

Guo, H., Xu, H., Tang, C., Liu-Thompkins, Y., Guo, Z., \& Dong, B. (2018). Comparing the impact of different marketing capabilities: Empirical evidence from B2B enterprises in China. J. Bus. Res., 93, 79-89.

Hashim, N.A.B., Raza, S., \&Minai, M.S. (2018). Relationship between Entrepreneurial Competencies and Small Enterprise Performance: Are Dynamic Capabilities the Missing Link? Academy Strategic Management Journal, 17, 1-10.

Hedvall, K., Jagstedt, S., \& Dubois, A. (2019). Solutions in business networks: Implications of an interorganizational perspective. J. Bus. Res., 4(3), 31-46. 
Ibidunni, O.S., \&Inelo, F. (2004). Market oriented strategic flexibility and market performance of the furniture industry in Southwest Nigeria under fierce competitive environment. SkyJournal of Business Administration \&Management, 3(1), 8-16.

Ibidunni, O.S., Iyiola, O., \&lbidunni, A.S. (2014). Product innovation, a survival strategy for small and medium enterprises in Nigeria. European Scientific Journal, 10(1), 194-209.

Industrial Development Report (2016). The role of technology and innovation in inclusive and sustainable industrial development. United Nations Industrial Development Organization (UNIDO. https://www.greengrowthknowledge.org/research/industrial-development-report-2016-roletechnology-and-innovation-inclusive-and-sustainable

Jegede, O.O., Ilori, M.O., Sonibare, J.A., Oluwale, B.A.,\&Siyanbola, W.O. (2012). Factors influencing innovation and competitiveness in the service sector in Nigeria: a sub-sectoral approach. Management, 2 (3), 69-79.

Kemper, J., Schilke, O., \& Brettel, M. (2013). Social capital as a microlevel origin of organizational capabilities. Journal of Product Innovation Management, 30(3), 589-603.

Machirori, T., \& Fatoki, O. (2013). The Impact of Enterprise and Entrepreneur's Characteristics on Networking by SMEs in South Africa. Journal of Economics, 4, 113-120.

Mohd, F., Mohd, S., \& Hoshino, Y. (2013). Sales growth, profitability and performance: empirical study of Japenese ICT industries with three Asean countries. Interdisciplinary Journal of Contemporary Research in Business, 4(11), 138-156.

Nimalathasan, B. (2009). Factor Analysis: Nature, Mechanism and Uses in Social \& Management Research. Journal of Cost \& Management Accountant Bangladesh, XXXVII (2), 15-25.

Obasi, C. (2013). Nigerian business environment daunting: Challenges and suggested solutions. British Journal of Economics, Finances and Management Sciences, 7(1), 47-52.

Obembe, J.J., Ojo, O.J.,\&llori, M.O. (2014). Effects of technological capabilities, innovations and clustering on the performance of enterprises in the Nigerian furniture industry. International Journal of Management Technology, 2(2), 19-28.

Oghojafor, B.E.A., Kuye, O.L., Ogunkoya, O.A., \&Shobayo, P.B. (2014). Competitive strategies, technological capabilities and organizational performance: Evidence from Nigerian manufacturing industry. Arabian Journal of Business and Management Review (Nigerian Chapter), 11-22.

Oladele, O.I., Akinsorotan, A.O., \&Ajadi, A.A. (2010). Knowledge and utilization of job enrichment techniques among agricultural extension managers in Botswana and Nigeria. The Journal of International Social Research, 3(12), 327-334.

Olamade, O.O., Oyebisi, T.O., \&Egbetokun, S.O. (2013). Manufacturing business environment in Nigeria strategic characteristics and implications. Advances inManagement and Applied Economics, 3(6), 53-65.

Oluwale, B.A., llori, M.O. \&Oyebisi, T.O. (2013). An assessment of technological capability building in the informal Nigerian automobile sector. Journal of Business and Management Sciences, 1(4), 55-62.

Rasiah, R. (2002). Government-business coordination and small enterprise performance in the machine tools sector in Malaysia. Small Business Economics, 18(1/3), 177-194. doi:10.1023/ A:1015139624218

Rehman, K.U., \& Saeed, Z. (2015). Impact of dynamic capabilities on enterprise performance: capabilities, form, \& function. Academy of Management Journal, 44, 1263-1278.

Rindova, V.P., \& Kotha, S. (2001). Continuous 'morphing': competing through dynamic capabilities, form, and function. Academy of Management Journal, 44, 1263-1278. 
Rodrigo-Alarcón, J., García-Villaverde, P.M., Ruiz-Ortega, M.J., \&Parra-Requena, G. (2018). From social capital to entrepreneurial orientation: The mediating role of dynamic capabilities. European Management Journal, 36, 195-209.

Seung, K.A. (2014). A study on the business ecosystem of German SMEs and its implications for Korean SMEs: Focusing on the hidden champion enterprises in Germany. Korean Journal of Economics Management, 32, 69-95.

Sherazi, S.K., Iqbal, M.Z., Asif, M., Rehman, K., \& Shah, S.H. (2013). Obstacles to small and medium enterprises in Pakistan. Principal component analysis approach. Middle East Journal Science Research, 13, 1325-1334.

Shimizu, K., \&Hitt, M.A. (2004). Strategic flexibility: Organizational preparedness to reverse ineffective strategic decisions. Academy of Management Executive, 18(4), 44-59.

Spearman, C. (1904). General intelligence objectively determined and measured. American Journal of Psychology, 15, 201-293.

Stock, E., \& Wennberg, K. (2009). The roles of R\&D in new enterprise growth. Management Research Journal,33(1), 77-89.

Teece, D. J., Pisano, G., \& Shuen, A. (1997). Dynamic capabilities and strategic management. Strategic Management Journal, 18(7), 509-533.

Teece, D. (2009). Dynamic capabilities and strategic management: Organizing for innovation\& growth. Oxford University Press.

Teece, D.J. (2012). Dynamic capabilities: Routines versus entrepreneurial action. Journal of Management Studies, 49 (8), 1395-1401.

Udemba, F. S. (2015). Understanding the food, beverages and tobacco operating environment. Manufacturing Association of Nigeria News, 17.

Wong, C., \& W.Y. (2013). Leveraging environmental information integration to enable environmental management capability and performance. Journal of Supply Chain Management, 49 (2), 114-136.

Zahra, S.A., Saprienza, H.J., \& Davidson, P. (2006). Entrepreneurship and dynamic capabilities: A review, model \& research agenda. Journal of Management Studies, 43 (4), 917-955.

Zhang, M.J. (2007). IS support for top managers' dynamic capabilities, environmental dynamism, and enterprise performance: An empirical investigation. Journal of Business \&Management, 13(1), 57-77.

Zhu, Q., Cordeiro, J., \& Sarkis, J. (2013). Institutional pressures, dynamic capabilities and environmental management systems: Investigating the ISO 9000-Environmental management system implementation linkage. J. Environ. Manag, 114, 232-242

Zikmund, W.G. (2003). Exploring marketing research (8th Edition). Thompson Learning/Southwestern, Cincinnati, $\mathrm{OH}$. 


\section{Authors}

The contribution share of authors is equal and amounted to $50 \%$ each of them.

\section{Zhou Lu Lin}

PhD holder in Economics and lecturer at the Department of Health and Economics Management Science and Engineering, Faculty of Management and Finance Professor. Zhou, specializes in Health Economics and international, economics and actively lectures and researches since 2001. Correspondence to: Department of Health and Economics Management Science and Engineering, Faculty of Management and Finance, Jiangsu University, Zhenjiang Jiangsu Province Post Code 212013 China; e-mail: zll62@ujs.edu.cn

ORCID (1) http://orcid.org/0000-0002-5266-2191

\section{James Onuche Ayegba}

M.B.A holder in management and PhD candidate in Department of Managements, Faculty of Management and Finance, Jiangsu University, Zhenjiang, Jiangsu province. He specializes in small and medium-sized enterprise (SME) and economics and actively lectures as graduate teaching assistant (GTA) and researches since 2017.

Correspondence to: Department of Marketing, Faculty of Management science and engineering, Jiangsu University, Zhenjiang Jiangsu province 212013 China; e-mail: 5103150216@stmail.ujs.edu.cn

ORCID (1) http://orcid.org/0000-0001-6127-4353

\section{Acknowledgements and Financial Disclosure}

The authors would like to thank the anonymous reviewers for their valuable reviews, which have improved the quality of this paper the reviewers for constructive comments that contributed to the robustness of the final draft of the research article.

\section{Copyright and License}

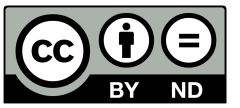

This article is published under the terms of the Creative Commons

Attribution - NoDerivs (CC BY-ND 4.0) License

http://creativecommons.org/licenses/by-nd/4.0/

Published by Cracow University of Economics - Krakow, Poland

Ministry of Science and Higher Education Republic of Poland
The journal is co-financed in the years $2019-2020$ by the Ministry of Science and Higher Education of the Republic of Poland in the framework of ministerial programme "Support for Scientific Journals" (WCN) on the basis of contract no. 238/WCN/2019/1 concluded on 15 August 2019. 
